\title{
Tüketicilerin gıda güvenilirliği konusunda farkındalıkları: Konya ili kent merkezi örneği
}

\author{
Awareness of consumers on food safety: the a case of Konya city center
}

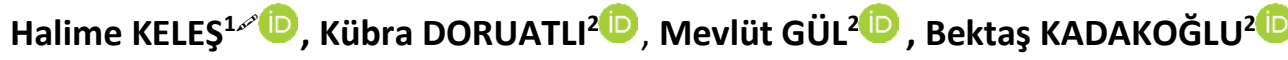 \\ ${ }^{1}$ Selcuk University, Faculty of Agriculture, Department of Agricultural Economics, Konya, Turkey. \\ ${ }^{2}$ Isparta University of Applied Sciences, Faculty of Agriculture, Department of Agricultural Economics, Isparta, Turkey.
}

MAKALE BILGISI / ARTICLE INFO

Makale tarihçesi / Article history:

DOI: $10.37908 /$ mkutbd.841100

Geliş tarihi /Received:16.12.2020

Kabul tarihi/Accepted:15.04.2021

\section{Keywords:}

Food safety, consumer, awareness, Konya.

\footnotetext{
Corresponding author: Mevlüt GÜL

$\triangle:$ mevlutgul@isparta.edu.tr
}

\section{ÖZET / A B STR A C T}

Atıf / Citation: Keleş H, Doruatıı K, Gül M,Kadakoğlu B (2021) Tüketicilerin gıda güvenilirliği konusunda farkındalıkları: Konya ili kent merkezi örneği. MKU. Tar. Bil. Derg. 26(2) : 316-325. DOI: 10.37908/mkutbd.841100

\section{Giriş}

Insanların yaşamlarını sürdürebilmeleri için en temel ihtiyaçların başında gelen gıda, artan dünya nüfusunun beslenme ihtiyacını karşılamakta zorlanmaktadır. Ayrıca insanların beslenme alışkanlıklarının değişmesiyle gıdaların tarladan sofraya gelene kadar geçtiği tüm aşamaların belirli kriterlere uygun şekilde üretiminin yapılması kaçınılmaz olmuştur.

Gıda güvenilirliği; gıdalardaki tehlikeli kimyasal, biyolojik, fiziksel faktörler kadar gıdaların tağşişi, Genetiği Değiştirilmiş Organizmalar ve gıdalar, beslenme, gıda güvenliği gibi konuları da kapsayan bir kavramdır (Kadim ve ark., 2014). Gıda güvenilirliği ve gıda güvenliği kavramlarının literatürde ve günlük hayatta sık sık karıştırıldığı görülmektedir. Bu kavramların Türkçe yazılışlarının birbirlerine yakın olması sebebiyle aralarındaki ayrımı yapabilmek kolay değildir. Gıda güvenliği kavramı daha çok arz yönlü ekonomik bir anlamı ifade ederken, gıda güvenilirliği kavramı ise gıdaların güvenilir ya da sağlıklı olması şeklinde tanımlanır. Dolayısıyla "food security" kavramı "gıda güvenliği", "food safety" kavramı ise "gıda güvenilirliği" ile özdeşleşmektedir (Gürsoy İba, 2013). 
Avrupa Birliği toplumunun daha sağlıklı ürünlere yönelmesi topluluğun gıda tüketim yapısını değiştirmiştir (Akpınar ve ark., 2007). Bununla birlikte Uluslararası Standartlar Örgütü (ISO-International Organization for Standardization) 1987 yılında yayınladığı ISO 9000 kalite yönetim sistemi standartlarıyla birlikte firmalar bu standartlar kapsamında üretimlerini gerçekleştirmişlerdir. AB ülkelerinin ithalatlarında da bu standartlar kapsamında üretilen ürünleri tercih etmesiyle beraber Türkiye'de bu konuda faaliyetler gerçekleştirilmiştir (Halaç, 2002). Gıda güvenilirliği yönetim sistemi için ISO standartları "ISO 22000" olarak adlandırılmıştır (Akpınar ve Gül, 2010). Diğer kalite güvence sistemi olan Çevre Yönetim Sistemi "ISO 14001" kavramı da ürünlerin müşteri talepleri doğrultusunda üretilmesinin yanında çevresel faktörleri göz önüne alarak üretilmesidir. HACCP (Hazard Analysis and Critical Control Points-Tehlike Analizi ve Kritik Kontrol Noktaları) ise hammaddeden son ürüne kadar bilimsel kontrollerin uygulanmasıyla gıdalarda meydana gelebilecek ve tüketici sağlığını direkt veya dolaylı yönden olumsuz etkileyebilecek tüm tehlikelerin daha oluşmadan engellenmesini amaçlayan bir sistemdir (Atayata, 2013). Bu çerçevede Türkiye'de 1990'lı yıllarda gıda güvencesi ve gıda güvenliği kavramları tartışılmaya başlanmış olup günümüzde her iki kavramı da kapsayan gıda güvenilirliği kavramı ön plana çıkmaktadır (Sağdıç ve Gül, 2016).

Son yıllarda gıda güvenliği konusunda birçok çalışma yapılmıştır (Karlı ve ark., 2008; Koç ve Ceylan, 2009; Ataseven ve ark., 2012; Gül ve ark., 2012a; Gül ve ark., 2012b; Taşdan ve ark., 2014; Dölekoğlu ve ark., 2015; Onurlubaş, 2015; Yılmaz ve ark., 2015; Gül ve ark., 2016; Onurlubaş ve Gürler, 2016; Gül ve ark., 2017; Durmaz Dayılar, 2018; Gürer ve Akyol, 2018; Madenci ve ark., 2019). Fakat tüketicilerin gıda güvenilirliği bilgisini araştıran ve gıda ürünlerini satın almada etkili olan faktörleri belirlemeyi amaçlayan çalışmalar sınırlıdır. Bu çalışma Konya ili merkez ilçelerinde yaşayan tüketicilerin gıda güvenilirliği konusundaki bilgi düzeylerini ve gıda satın alma davranışlarında etkili olan faktörleri belirlemek amacıyla gerçekleştirilmiş olup tüketicilerin gıda güvenilirliği bilgileri ile sosyo-ekonomik özellikleri arasındaki ilişkinin belirlenmesi amaçlanmıştır.

\section{MATERYAL ve YÖNTEM}

\section{Materyal}

$\mathrm{Bu}$ çalışmanın ana materyalini, Konya ili merkez ilçelerindeki tüketiciler ile yüz yüze yapılan anket sonuçlarından elde edilen birincil veriler oluşturmuştur. Ayrıca konuyla ilgili yerli ve yabancı makaleler, araştırmalar, projeler ve tezler gibi dokümanlardan elde edilen verilerden de faydalanılmıştır.

\section{Yöntem}

Pazarlama alanında yapılan çalışmalarda, uygulamada farklı ana kitle büyüklükleri ve tolerans düzeyleri için belirli güven sınırları ve belirli ana kitle varyansı varsayılarak farklı örnek büyüklükleri kullanılmaktadır (Kurtuluş, 1998). Çalışmada kentsel alanda ikamet eden hane halklarının en azından \%50'sinin gıda güvenilirliği konusunda bilgili olduğu, bu ortalamadan \pm 0.05 yanılabileceği ve \%95 güvenilirlik düzeyinde, araştırmada örnek büyüklüğü aşağıda formülasyon ile saptanmıştır (Kurtuluş, 1998).

$$
(p \times q)
$$

$N=z^{2}$ $=(1.96)^{2}$ $=384$

$$
d^{2} \quad(0.05)^{2}
$$

z: \%95 güven düzeyi; $p$ : İncelenen konuyla ilgili ana kitle oranı; q: ilgili özelliğe sahip olmayan ana kitle oranı; d: Kabul edilen hata düzeyi.

Çalışmada yapılan hesaplamalar sonucunda örneklem genişliği 384 hane halkı olarak hesaplanmıştır. Anket dağılımı; kent yapısı, mahalle sayısı, nüfus sayısı göz önünde tutularak yapılmıştır. İlde anket yapılacak ilçeler, TÜik tarafından ve İlçe Nüfus Müdürlüklerinden alınan bilgiler doğrultusunda belirlenmiştir. Buna göre Selçuklu ilçesinde 194 tüketici, Meram ilçesinde 114 tüketici, Karatay ilçesinde 76 tüketici hedef ana kitle olarak belirlenmiştir. Hane halklarının farklı gelire sahip olmaları tüketim davranışlarını etkileyeceği için bu çalışmada hane halkı gelir grupları oluşturulmuştur. Tüketicilerin gruplara ayrılmasında ailelerin ortalama geliri esas alınmış; düşük, orta ve yüksek gelirli olmak üzere üç grupta incelenmiştir. Gelir gruplandırmasında asgari ücret kıstas alınmış ve her ailede yaklaşık 2 kişinin çalıştığı varsayılmıştır. Bu noktada, gelir grupları 2,500 TL'den az olan aileler "I. Grup", 2,501 - 5,000 TL arası geliri olan aileler "II. Grup", ve 5,001 TL ve üstü geliri olan aileler "III. Grup" olarak tanımlanmıştır (Çizelge 1). Araştırmada elde edilen veriler, gelir grupları ile çapraz tablo yapılarak analiz edilmiştir. Anket çalışmaları 2018 yılı Ağustos ayında gerçekleştirilmiştir.

Gıda güvenirliğini bilme ile sürekli değişkenlerin karşılaştırılmasında varyans analizi yapılmıştır. Varyans analizi iki ya da daha fazla grubun ortalamaları arasındaki farkın anlamlılığı için ilgili hipotezleri test etmede kullanılmaktadır (Özdamar, 1999). 
Çizelge 1. Ankete katılan tüketicilerin gelirlerine göre dağılımı

Table 1. Distribution of the consumers surveyed by their income

\begin{tabular}{lccc}
\hline $\begin{array}{l}\text { Gelir } \\
\text { grupları }\end{array}$ & $\begin{array}{c}\text { Gelir düzeyi } \\
\text { (ay/TL) }\end{array}$ & Sayı (n) & Yüzde (\%) \\
\hline I & 2,500 TL'ye kadar & 159 & 41.41 \\
II & $2,501-5,000$ TL & 159 & 41.41 \\
III & 5,001 TL ve üzeri & 66 & 17.18 \\
\hline Toplam & & 384 & 100.00 \\
\hline
\end{tabular}

\section{BULGULAR ve TARTIŞMA}

Hane halkının ve bireysel tüketicilerin sağlıklı ve objektif belirleyicileri demografik özellikleridir. Birçok ürün piyasası tüketicilerin demografik özelliklerinden direkt olarak etkilenmekte ve tüketicilerin bu özellikleri işletmeler tarafından hedef pazarı belirlerken kullanılmaktadır (Asseal, 1992; Onurlubaş, 2015). Aynı şekilde tüketiciler ile ilgili sosyo-demografik değişkenler tüketicilerin ürünlerle ilgili satın alma, tüketim, yargı ve kararları üzerinde etkilidir (Gül ve ark., 2016). Bu yüzden çalışma kapsamında öncelikli olarak tüketici ve hane halkına ilişkin sosyo-demografik özellikler incelenmiştir. Görüşme yapılan tüketicilerin \%57.29'u erkek, \%42.71'i kadındır. I. gelir grubunda görüşme yapılan tüketicilerin \%54.72'si erkek, \%45.28'i kadındır. II. gelir grubunun \%62.26'sı erkek, \%37.74'ü kadındır. III. gelir grubunun ise \%51.52'si erkek, \%48.48'i kadındır. Tüketicilerin \%51.82'si evli, \%43.23'ü bekâr ve \%4.95'i boşanmıştır. I. gelir grubunun \%49.06'sı bekâr, \%45.91'i evli, \%5.03'ü boşanmıştır. II. gelir grubunun $\% 55.35^{\prime} \mathrm{i}$ evli, $\% 40.25^{\prime} \mathrm{i}$ bekâr, \%4.40'। ise boşanmış ve III. gelir grubunun \%57.58'i evli, \%36.36'sı bekâr, \%4.95'i boşanmıştır. Tüketicilerin \%30.99'u 18-25 yaş grubunda, \%22.66'sı 26-30 yaş grubunda, \%21.88'i $31-40$ yaş grubunda ve $\% 24.47$ 'si de 41 ve daha yukarı yaştadır. Tüketicilerin \%66.41'i kentte doğmuş ve \%33.59'u kırsal alanda doğmuştur. Gelir gruplarına göre bakıldığında I. gelir grubundaki tüketicilerin $\% 68.55^{\prime} i$ kent, $\% 31.45^{\prime} i \mathrm{kır}$ kökenlidir. II. gelir grubunun \%63.52'si kent, \%36.48'i kır kökenli ve III. gelir grubunun ise \%68.18'i kent, \%31.82'si kır kökenlidir. Görüşülen tüketicilerin $\% 46.09^{\prime}$ u üniversite mezunu, \%35.42'si lise mezunu, \%11.71'i ilk ve ortaokul mezunu, \%3.13'ü herhangi bir okul mezunu olmayıp okuma yazma bilmekte ve \%3.39'u lisansüstü mezunudur. I. gelir grubunda $\% 40.88$ ile en fazla lise mezunu bulunmaktadır ve bunu \%33.33 ile üniversite mezunu takip etmektedir. II. gelir grubunda ise en fazla \%57.23 ile üniversite mezunu bulunmakta ve \%30.82 ile lise mezunu onu takip etmektedir. III. gelir grubunda \%46.09 ile en fazla üniversite mezunu bulunmakta olup bunu \%35.42'i ile lise mezunu takip etmektedir. Tüketicilerin \%28.91'i işçi, \%25.26'sı serbest meslekle uğraşmakta, \%20.31'i memur, \%2.86'sı emekli, \%22.66'sı ise işsizdir (Çizelge 2).

Aynı ilde yapılan bir çalışmada ise 400 tüketici ile görüşülmüş ve görüşülen tüketicilerin $\% 49^{\prime}$ u kadın $\% 51^{\prime} i$ ise erkektir. Araştırmaya katılan tüketicilerin \%58,3'ü üniversite mezunu, $\% 11,6$ 'sı lise mezunu olduğunu belirtmiştir. Tüketicilerin \%25.4'ü işçi, \%18'i memur, \%12.2'si ise işsiz olduğunu belirtmiştir (Durmaz Dayılar, 2018). Yine aynı ilde yapılan bir başka çalışmada 383 tüketici ile görüşülmüştür. Görüşme yapılan tüketicilerin \%67'si erkek, \%33'ü kadındır. Tüketicilerin \%50'si 26-40 yaş aralığında olup \%22'si 41-50 yaş aralığındadır. Tüketicilerin \%84'ü evli, \%13'ü bekâr ve \%3'ü boşanmıştır (Madenci ve ark., 2019). Ankara ili kent merkezinde yapılan çalışmada 260 tüketici ile görüşülmüş tüketicilerin \%64.2'si kadın, \%35.8'i erkek, $\% 80^{\prime}$ inin 30 yaşın üzerinde, $\% 74.2^{\prime}$ sinin evli ve $\% 71.5^{\prime} \mathrm{i}$ de herhangi bir işte çalışır durumda olduğu belirtilmiştir (Taşdan ve ark., 2014). Isparta ilinde yapılan çalışmada 384 tüketici ile görüşülmüş ve görüşülen tüketicilerin \%55'i kadın, \%45'i erkek, \%46.5'i 18-34 yaş grubunda, \%55.00'ı evli, \%40.75'i bekâr, \%14.25'i kamuda, \%22'si özel sektörde çalıştığı, \%17'si ev hanımı, \% 7.25'i emekli, $\% 12$ 'sinin ise işsiz olduğu tespit edilmiştir (Gül ve ark., 2016). Tokat ilinde yapılan çalışmada 401 tüketici ile görüşülmüş ve görüşülen tüketicilerin \%57.9'unu erkekler, \%42.1'ini ise kadınlar oluşturmaktadır. Tüketicilerin \%70.8'i evli, \%24.4'ü bekâr ve \%4.8'i boşanmıştır. Görüşülen kişilerin $\% 51.6$ 'sı $31-50$ yaş aralığında, \%34.2'si 18-30 yaş aralığındadır. Tüketicilerin \%63.6'sı kent kökenli olup \%36.4'ü kır kökenlidir. Tüketicilerin \%39.9'u lise, \%20.7'si üniversite, \%20'si ilkokul ve $\% 13^{\prime}$ ü ortaokul mezunu olduğunu belirtmişlerdir (Onurlubaş ve Gürler, 2016).

Tüketicilerin Konya kent merkezinde ikamet ettikleri süre 21.67 yıldır. I. gelir grubu 22.31 yıldır, II. gelir grubu 21.23 yıldır, III. gelir grubu ise 21.20 yıldır Konya kent merkezinde ikamet ettiği tespit edilmiştir. Ortalama hane genişliği 3.5 kişidir. I. gelir grubunda 3.36 kişi, II. gelir grubunda 3.59 kişi, III. gelir grubunda ise 3.61 kişi olduğu saptanmıştır. Tüketicilerin ortalama hanede çalışan sayısı 1.5 kişidir. I. gelir grubunda 1.23 kişi, II. gelir grubunda 1.53 kişi, III. gelir grubunda ise 2.06 kişi olduğu tespit edilmiştir (Çizelge 3 ). 
Çizelge 2. Görüşülen bireylerin sosyo-demografik özellikleri

Table 2. Socio-demographic characteristics of the individuals surveyed

\begin{tabular}{|c|c|c|c|c|c|c|c|c|}
\hline \multirow{2}{*}{ Özellikler } & \multicolumn{2}{|c|}{1} & \multicolumn{2}{|c|}{ II } & \multicolumn{2}{|c|}{ III } & \multicolumn{2}{|c|}{ Toplam/Ortalama } \\
\hline & $\mathrm{N}$ & $\%$ & $\mathrm{~N}$ & $\%$ & $\mathrm{~N}$ & $\%$ & $\mathrm{~N}$ & $\%$ \\
\hline \multicolumn{9}{|l|}{ Cinsiyet } \\
\hline Kadın & 72 & 45.28 & 60 & 37.74 & 32 & 48.48 & 164 & 42.71 \\
\hline Erkek & 87 & 54.72 & 99 & 62.26 & 34 & 51.52 & 220 & 57.29 \\
\hline \multicolumn{9}{|l|}{ Medeni durum } \\
\hline Evli & 73 & 45.91 & 88 & 55.35 & 38 & 57.58 & 199 & 51.82 \\
\hline Bekâr & 78 & 49.06 & 64 & 40.25 & 24 & 36.36 & 166 & 43.23 \\
\hline Boşanmış & 8 & 5.03 & 7 & 4.40 & 4 & 6.06 & 19 & 4.95 \\
\hline \multicolumn{9}{|c|}{ Bireylerin yaş dağılımı } \\
\hline $18-25$ & 56 & 35.22 & 47 & 29.56 & 16 & 24.24 & 119 & 30.99 \\
\hline $26-30$ & 43 & 27.04 & 31 & 19.50 & 13 & 19.70 & 87 & 22.66 \\
\hline $31-40$ & 31 & 19.50 & 37 & 23.27 & 16 & 24.24 & 84 & 21.88 \\
\hline $41-50$ & 17 & 10.69 & 25 & 15.72 & 14 & 21.21 & 56 & 14.58 \\
\hline $51-60$ & 11 & 6.92 & 14 & 8.81 & 5 & 7.58 & 30 & 7.81 \\
\hline $60+$ & 1 & 0.63 & 5 & 3.14 & 2 & 3.03 & 8 & 2.08 \\
\hline \multicolumn{9}{|l|}{ Doğum yeri } \\
\hline Kır & 50 & 31.45 & 58 & 36.48 & 21 & 31.82 & 129 & 33.59 \\
\hline Kent & 109 & 68.55 & 101 & 63.52 & 45 & 68.18 & 255 & 66.41 \\
\hline \multicolumn{9}{|l|}{ Eğitim durumu } \\
\hline Okur-Yazar Değil & 0 & 0.00 & 1 & 0.63 & 0 & 0.00 & 1 & 0.26 \\
\hline Okur-Yazar & 5 & 3.14 & 3 & 1.89 & 4 & 6.06 & 12 & 3.13 \\
\hline İlkokul Mezunu & 19 & 11.95 & 4 & 2.52 & 0 & 0.00 & 23 & 5.98 \\
\hline Ortaokul Mezunu & 16 & 10.06 & 6 & 3.77 & 0 & 0.00 & 22 & 5.73 \\
\hline Lise Mezunu & 65 & 40.89 & 49 & 30.82 & 22 & 33.33 & 136 & 35.42 \\
\hline Üniversite Mezunu & 53 & 33.33 & 91 & 57.23 & 33 & 50.00 & 177 & 46.09 \\
\hline Lisans Üstü & 1 & 0.63 & 5 & 3.14 & 7 & 10.61 & 13 & 3.39 \\
\hline \multicolumn{9}{|l|}{ Sosyal statü } \\
\hline Memur & 3 & 1.88 & 50 & 31.45 & 25 & 37.88 & 78 & 20.31 \\
\hline İşçi & 69 & 43.40 & 34 & 21.37 & 8 & 12.12 & 111 & 28.91 \\
\hline Serbest Meslek & 36 & 22.64 & 39 & 24.53 & 22 & 33.33 & 97 & 25.26 \\
\hline Emekli & 4 & 2.52 & 4 & 2.52 & 3 & 4.55 & 11 & 2.86 \\
\hline Çalışmıyor & 47 & 29.56 & 32 & 20.13 & 8 & 12.12 & 87 & 22.66 \\
\hline
\end{tabular}

Isparta ili kent merkezinde yapılan çalışmada kentte ikamet süresini yaklaşık 25 yıl, hane genişliği 3.94 kişi, hanede çalışan kişi sayısını 1.54 kişi olarak tespit edilmiştir (Gül ve ark., 2016). Tokat ilinde yapılan çalışmada ise tüketicilerin $\% 32.5$ 'i 30 yıldan fazla süredir Tokat'ta yaşamaktayken, \%20.2'si 9 yıldan daha az süredir Tokat'ta yaşadığını belirtmiştir. Ortalama hane genişliğini ise yaklaşık 4 kişi olarak tespit etmişlerdir (Onurlubaş ve Gürler, 2016).

Çalışmada hanelerin aylık ortalama gelirleri 4,929.92 TL, giderleri ise 3,869.79 TL olarak tespit edilmiştir. Araştırmaya katılan tüketicilerin gıda harcamasına bakıldığında aylık ortalama 1,134.01 TL gıda harcaması yaptıkları tespit edilmiştir. I. gelir grubundaki bireylerin ayda $617.61 \mathrm{TL}$, II. gelir grubundaki bireylerin ayda
1,212.96 TL, III. gelir grubundaki bireylerin ise ayda 2,187.88 TL gıda harcaması yaptıkları saptanmıştır. Tüketicilerin gıda harcamasının toplam harcama içindeki payı ortalama \%29.30'dur. I. gelir grubundaki bireylerin \%31.68, II. gelir grubundaki bireylerin \%31.46, III. gelir grubundaki bireylerin ise $\% 25.65$ 'dir. Toplam gelir içindeki gıda harcamasının payı \%23 olup I. gelir grubundaki bireylerin \%27.91, II. gelir grubundaki bireylerin \%25.13, III. gelir grubundaki bireylerin ise $\% 18.66$ 'dır. Tüketiciler aylık gelirlerinin \%21.50'sini tasarruf ettiklerini belirtmişlerdir. En yüksek tasarrufu \%27.26 ile III. gelir grubundaki tüketiciler yapmakta olup en düşük tasarrufu ise \%11.89 ile I. gelir grubundaki tüketiciler yapmaktadır (Çizelge 4). 
Çizelge 3. Tüketicilerin şehir merkezinde ikamet süresi, hane genişliği ve çalışan sayısı

Table 3. Consumers residence time in the city center, number of people and employees in the household

\begin{tabular}{lccc}
\hline $\begin{array}{l}\text { Gelir } \\
\text { grupları }\end{array}$ & $\begin{array}{c}\text { Konya'da } \\
\text { ikamet süresi } \\
\text { (yıl) }\end{array}$ & $\begin{array}{c}\text { Hane } \\
\text { genişliği } \\
\text { (kişi) }\end{array}$ & $\begin{array}{c}\text { Hanede } \\
\text { çalışan sayısı } \\
\text { (kişi) }\end{array}$ \\
\hline I & 22.31 & 3.36 & 1.23 \\
II & 21.23 & 3.59 & 1.53 \\
III & 21.20 & 3.61 & 2.06 \\
\hline Ortalama & 21.67 & 3.50 & 1.50 \\
\hline
\end{tabular}

Aynı ilde yapılan çalışmada tüketicilerin aylık ortalama gelirinin 2,500 TL olduğu, gıda harcamalarının toplam gelir içerisindeki payını \%30 olarak (750 TL) tespit etmişlerdir (Durmaz Dayılar, 2018). Yine aynı ilde yapılan bir çalışmada tüketicilerin \%77'sinin 1,501-5,000 TL aylık aile gelirlerinin olduğu belirtilmiştir (Madenci ve ark., 2019). Isparta ili kent merkezinde yapılan bir diğer çalışmada ise ailelerin aylık ortalama gelirlerini 3,168.51 TL olarak belirlenmiş ve gıda harcaması 563.18 TL olup toplam gelirin \%17.77'sinin gıda harcamalarına ayrıldığı saptanmıştır (Gül ve ark., 2016). Tüketicilerin hane gelirleri ile giderleri ve dolayısıyla gıda harcamaları arasında doğru orantılı bir ilişki söz konusudur. Hane gelirleri arttıkça gıda harcamaları da artmaktadır. Fakat gelir arttıkça gıda harcamalarının toplam gelir içerisindeki payları azalmaktadır.

Çizelge 4. Tüketicilerde aylık ortalama hane geliri, gideri ve gıda harcaması

Table 4. Consumers average monthly household income, expenses and food spending

\begin{tabular}{lcccccc}
\hline Gelir grupları & Gelir (TL/ay) & Gider (TL/ay) & $\begin{array}{c}\text { Gıda harcaması } \\
\text { (TL/ay) }\end{array}$ & $\begin{array}{c}\text { Gıda harcamasının Gıda harcamasının } \\
\text { toplam gelir } \\
\text { içindeki payı (\%) }\end{array}$ & $\begin{array}{c}\text { Tasarruf } \\
\text { toplam harcama } \\
\text { içindeki payı (\%) }\end{array}$ & $\begin{array}{c}\text { oranı (\%) } \\
\text { orind }\end{array}$ \\
\hline I & $2,212.89$ & $1,949.69$ & 617.61 & 27.91 & 31.68 & 11.89 \\
II & $4,826.67$ & $3,855.97$ & $1,212.96$ & 25.13 & 31.46 & 20.11 \\
III & $11,724.24$ & $8,528.79$ & $2,187.88$ & 18.66 & 25.65 & 27.26 \\
\hline Ortalama & $4,929.92$ & $3,869.79$ & $1,134.01$ & 23.00 & 29.30 & 21.50 \\
\hline
\end{tabular}

Tüketicilerin ambalajlı ve ambalajsız satılan gıda ürünlerini satın alma kararında etkili olan faktörler Çizelge 5'de verilmiştir. Buna göre ambalajlı gıda ürünü satın alma kararında birincil faktörün son kullanma tarihi olduğu bunu etiket bilgileri ve muhafaza koşullarının izlediği belirlenmiştir. Ambalajsız gıda ürünlerinde ise satın alma kararında birincil faktörün satıldığı yer olduğu bunu muhafaza koşulları ve üretim yerinin (yerli/ithal) izlediği tespit edilmiştir.

Ankara ilinde yapılan çalışmada tüketicilerin gıda ürünlerini satın alırken dikkat ettikleri kriterlerin en önemlileri olarak üretim ve son kullanma tarihi, tazelik ve fiyat olduğu belirtilmiştir (Taşdan ve ark., 2014). Isparta ilinde yapılan bisküvi ürünlerini satın almada tüketicilerin dikkat ettikleri en önemli faktörlerin kalite, fiyat kalite düzeyi ve marka olduğu saptanmıştır (Gül ve ark., 2016). Tokat ilinde yapılan çalışmada tüketiciler gıda ürünlerini satın alırken ilk olarak üretim yapıldığı yerdeki hijyeni ve ürünlerin ambalajlarının sağlığa zararlı olmamasını önemli bulmuşlardır (Onurlubaş ve Gürler, 2016). Konya ilinde yapılan çalışmada ise en önemli faktörler olarak üretilen yerin hijyeni, gıdanın sağlıklı olması ve ambalajın sağlığa zararlı olmaması şeklinde sıralanmıştır (Madenci ve ark., 2019). Tüketiciler gıda ürünlerini satın alırken öncelikli olarak sağlık bakımından etkili olan faktörleri dikkate aldıkları görülmektedir.

Görüşme yapılan tüketicilerin $\% 87.5^{\prime}$ inin gıda güvenilirliği kavramını duyduğu, \%12.5'inin ise duymadığı tespit edilmiştir. Gelir gruplarına göre bakıldığında I. gelir grubundaki tüketicilerin \%86.16'sının gıda güvenilirliği kavramını duyduğu, \%13.84'ünün duymadığı saptanmıştır. II. gelir grubundaki tüketicilerin \%88.05'inin gıda güvenilirliği kavramını duyduğu, \%11.95'inin duymadığı saptanmıştır. III. gelir grubundaki tüketicilerin ise \%89.39'unun gıda güvenilirliği kavramını duyduğu, \%10.61'inin duymadığı saptanmıştır (Çizelge $6)$. 
Çizelge 5. Tüketicilerde gıda ürünleri satın alma kararlarında etkili olan faktörler (ortalama)

Table 5. Factors influencing consumers food products purchasing decisions (mean)

\begin{tabular}{|c|c|c|c|c|}
\hline \multirow{2}{*}{ Faktörler } & \multicolumn{3}{|c|}{ Gelir grupları } & \multirow{2}{*}{ Ortalam } \\
\hline & 1 & II & III & \\
\hline \multicolumn{5}{|l|}{ Ambalajlı Gıda Ürünleri } \\
\hline Son kullanma tarihi & 4.61 & 4.52 & 4.45 & 4.54 \\
\hline Etiket bilgileri & 4.36 & 4.11 & 4.32 & 4.29 \\
\hline Muhafaza koşulları & 4.45 & 4.13 & 4.24 & 4.28 \\
\hline İçindekiler & 4.42 & 4.01 & 3.97 & 4.17 \\
\hline Gıda güvenilirliği belgesi & 4.13 & 4.14 & 4.02 & 4.12 \\
\hline Kalite güvence belgesi & 4.21 & 4.06 & 3.94 & 4.10 \\
\hline Besin değeri & 4.03 & 3.97 & 3.94 & 3.99 \\
\hline Üretim yeri (yerli/ithal) & 4.11 & 3.86 & 3.56 & 3.91 \\
\hline Organik ürün belgesi & 3.86 & 3.68 & 3.71 & 3.76 \\
\hline Marka & 3.67 & 3.55 & 3.77 & 3.61 \\
\hline Renk/Materyal/Görsel & 3.77 & 3.42 & 3.67 & 3.60 \\
\hline \multicolumn{5}{|l|}{ Ambalajsız Gıda Ürünleri } \\
\hline Satıldığı yer & 4.48 & 4.35 & 4.61 & 4.45 \\
\hline Muhafaza koşulları & 4.47 & 4.39 & 4.42 & 4.43 \\
\hline Üretim yeri (yerli/ithal) & 4.22 & 4.09 & 4.30 & 4.18 \\
\hline Fiyatı & 4.13 & 3.94 & 3.92 & 4.01 \\
\hline Promosyonlu Satış & 1.47 & 3.00 & 2.71 & 3.19 \\
\hline
\end{tabular}

$\begin{array}{lllll}\text { Ölçek: 1. Hiç önemli değil } & \text { 2. Önemli değil } & \text { 3. Ne önemsiz-ne önemli } & \text { 4. Önemli } & \text { 5. Çok önemli }\end{array}$

Ankara ili kent merkezinde yapılan bir çalışmada tüketicilerin \%80'i gıda güvenilirliğini bildiğini (Taşdan ve ark., 2014), Tokat ili merkez ilçede yapılan çalışmada tüketicilerin \%68.6'sı gıda güvenliği kavramını duyduğunu (Onurlubaş ve Gürler, 2016), Konya ili merkez ilçelerinde yapılan çalışmada tüketicilerin \%73.4'ü bu kavram hakkında bilgi sahibi olduğu (Durmaz
Dayılar, 2018), Niğde ili kent merkezinde yapılan bir başka çalışmada ise 286 tüketiciyle görüşülmüş ve tüketicilerin \%80.1'i gıda güvenilirliğinin ne olduğunu bildiklerini belirtmişlerdir (Gürer ve Akyol, 2018). Yapılan çalışmalarda da görüleceği üzere kent merkezlerindeki tüketicilerin gıda güvenilirliğini tanıma oranları yüksektir.

Çizelge 6. Tüketicilerin gıda güvenilirliğini duyma durumları

Table 6. Consumers knowledge of food safety

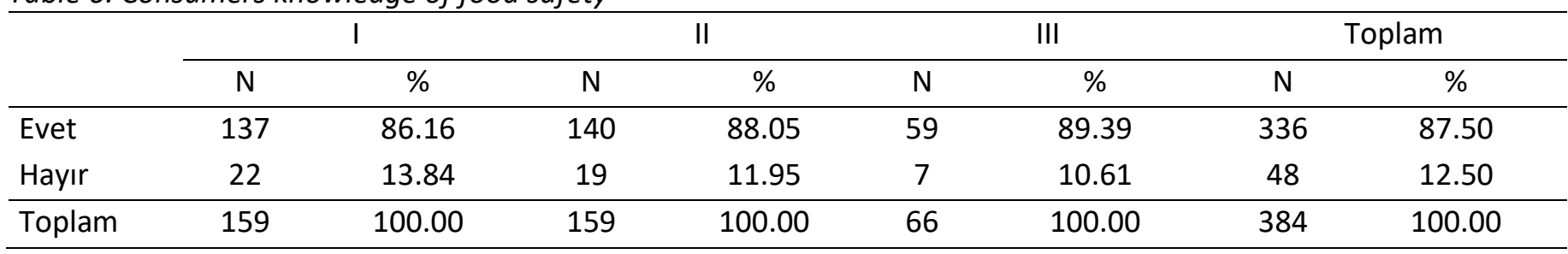

Şekil 1'de tüketicilerin gıda güvenilirliğini tanımları verilmiştir. Görüşme yapılan tüketicilere $A, B$ ve $C$ şeklinde 3 farklı tanım sunulmuş ve tüketiciler bu tanımlamalardan birini seçmişlerdir. Buna göre I. gelir grubunun \%54.72'si gıda güvenilirliğini gıdaların üretimden tüketime kadar her aşamasında gerekli kurallara uyulması ve önlemlerin alınması, sağlıklı, sağlığa yararlı gıda maddelerinin üretilmesi olarak tanımlarken, \%16.35'i gıdaların her türlü tehlikeye karşı güvenliğini sağlamak olarak tanımlamıştır. Tüketicilerin \%14.47'si ise tüketicilerin yeterince gıdaya ulaşmalarını sağlamaktır cevabını vermiştir. II. gelir grubunun \%54.72'si C seçeneğini, \%19.50'si B seçeneğini, \%14.47'si ise A seçeneğini seçmişlerdir. III. gelir grubu ise diğer gruplara nazaran daha yüksek bir oranla \%68.18'i C seçeneğini seçmiştir. Sonra sırasıyla \%15.15'i B seçeneğini, \%6.06'sı ise A seçeneğini seçmişlerdir. 


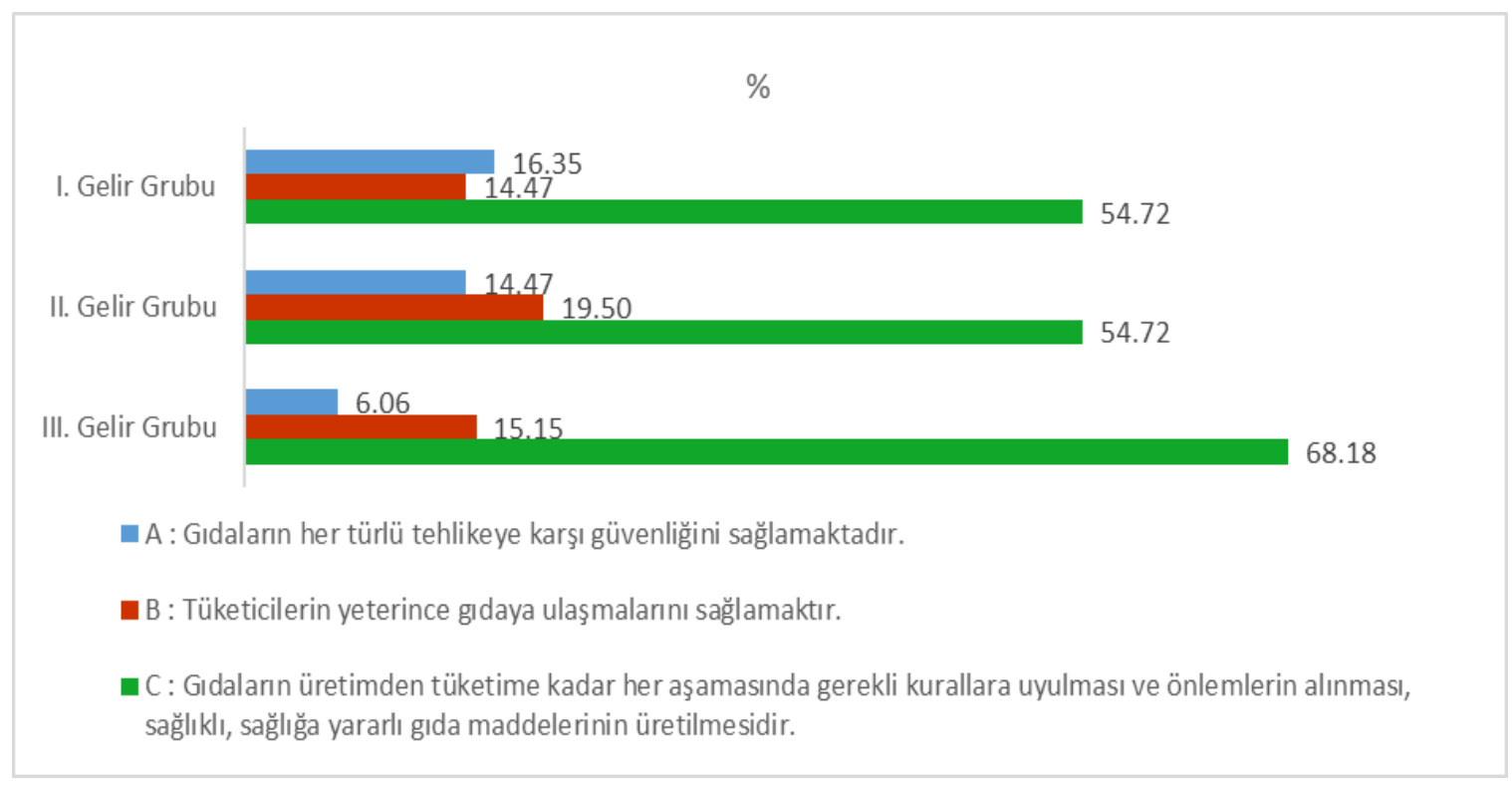

Şekil 1. Tüketicilerin gıda güvenilirliği tanımları

Figure 1. Consumers definitions of food safety

Çizelge 7'de görüşülen tüketicilerin gıda güvenilirliği konusunda bilgi edindikleri kaynaklar verilmiştir. Tüketicilerin bilgi edindikleri kaynaklardan ilk sırayı \%58.59 ile radyo, TV programları yer alırken, ikinci sırada \%21.09 ile ahbap, eş, dost gelmektedir. Tüketicilerin $\% 12.50$ 'sinin ise bilgisi yoktur. Gelir gruplarına göre tüketicilerin gıda güvenilirliği konusundaki bilgi kaynaklarına bakıldığında I. gelir grubundaki tüketiciler ilk olarak \%68.55 ile radyo, TV programlarından, ikinci olarak ise \%21.38 ile ahbap, eş, dosttan bilgi edindikleri görülmektedir. II. gelir grubundaki tüketiciler ilk olarak \%54.72 ile radyo, TV programlarından, ikinci olarak ise \%21.38 ile ahbap, eş, dosttan bilgi edindikleri görülmektedir. III. gelir grubundaki bireyler ilk olarak \%43.94 ile radyo, TV programlarından, ikinci olarak \%27.27 ile konu uzmanlarından bilgi edindikleri görülmektedir.

Konya ili merkez ilçelerinde yapılan bir çalışmada tüketicilerin gıda güvenilirliği konusunda bilgi edindikleri kaynaklar araştırılmış ve \%33'ü televizyon reklamlarından, \%26'sı internet reklamlarından, \%17'si ise arkadaş, akraba ve komşudan bilgi edindiklerini belirtmişlerdir (Madenci ve ark., 2019). Yine aynı ilde yapılan çalışmada araştırmaya katılan tüketiciler yüksek oranda bilgi edindikleri kaynakları \%42.3 internet, \%41.3'ü radyo ve TV programları, \%24.5'i konu uzmanları olarak bildirmiştir (Durmaz Dayılar, 2018). Ankara ilinde yapılan çalışmada ise tüketiciler \%46.92'ile yakın çevreden, \%36.92 ile radyon, TV programlarından bilgi edindiklerini belirtmişlerdir (Taşdan ve ark., 2014). Tokat ilinde yapılan çalışmada da tüketiciler yüksek oranda bilgi edindiği kaynağını \%78.9 ile radyo ve TV programları olduğunu belirtmişlerdir (Onurlubaş ve Gürler, 2016). Yapılan çalışmalar sonucunda radyo ve TV programlarının gıda güvenilirliği konusunda en önemli bilgi kaynağı olduğunun ortaya koymaktadır.

Çizelge 7. Tüketicilerin gıda güvenilirliği konusunda bilgi edindikleri kaynaklar

Table 7. Sources from which consumers get information about food safety

\begin{tabular}{lcccccccc}
\hline \multirow{2}{*}{ Bilgi kaynakları } & \multicolumn{3}{c}{$\mathrm{I}$} & \multicolumn{3}{c}{ II } & \multicolumn{1}{c}{ III } & \multicolumn{2}{c}{ Toplam } \\
\cline { 2 - 9 } & $\mathrm{N}$ & $\%$ & $\mathrm{~N}$ & $\%$ & $\mathrm{~N}$ & $\%$ & $\mathrm{~N}$ & $\%$ \\
\hline Radyo, TV programları & 109 & 68.55 & 87 & 54.72 & 29 & 43.94 & 225 & 58.59 \\
Ahbap, eş, dost & 34 & 21.38 & 34 & 21.38 & 13 & 19.7 & 81 & 21.09 \\
Konu uzmanları & 20 & 12.58 & 32 & 20.13 & 18 & 27.27 & 70 & 18.23 \\
Gazete, dergi vd. & 19 & 11.95 & 23 & 14.47 & 13 & 19.7 & 55 & 14.32 \\
Bilimsel yazı, kitap & 4 & 2.52 & 24 & 15.09 & 13 & 19.7 & 41 & 10.68 \\
Bilgim yok & 22 & 13.84 & 19 & 11.93 & 7 & 10.61 & 48 & 12.50 \\
\hline
\end{tabular}

*Tüketiciler birden fazla seçenek seçmişlerdir. 
Çizelge 8'de tüketicilerin gıda ürünleri kalitesinin değerlendirilmesine kullanılan bazı kavramların (ISO ve HACCP) bilinirliği sorgulanmıştır. Buna göre ISO 9001, araştırma kapsamında görüşülen tüketicilerin \%68.23'ü tarafından bilinmektedir. Gıda güvenilirliğinin sağlanması bakımından önemli olan ISO 22000, HACCP ve ISO 14001 standardı görüşülen tüketiciler tarafından daha az bilinmektedir. ISO 22000 standardı tüketicilerin $\% 36.98^{\prime} i$, HACCP \%34,11'i ve ISO 14001 sertifikası ise \%17.19'u tarafından tanınmaktadır. Gelir seviyesi arttıkça bu standartların bilinirliği de artmaktadır. Gelir gruplarına göre bakıldığında ise I. gelir grubunun gıda güvenirliliği sertifikalarından en çok \%66.67 ile ISO 9001'i duydukları görülmektedir. Daha sonra sırasıyla \%28.3 ile ISO $22000, \% 21.38$ ile HACCP ve \%9.43 ile ISO 14001 ' $i$ duydukları görülmektedir. II. gelir grubunun gıda güvenirliliği sertifikalarından en çok \%70.44 ile ISO 9001'i duydukları görülmekte olup daha sonra sırasıyla \%42.14 ile HACCP, \%41.51 ile ISO 22000 ve \%22.01 ile ISO 14001 gelmektedir. III. gelir grubunun gıda güvenirliliği sertifikalarından en çok \%66.67 ile ISO 9001'i duydukları görülmektedir. Daha sonra sırasıyla \%46.97 ile ISO
22000, \%45.45 ile HACCP ve \%24.24 ile ISO $14001^{\prime} \mathrm{i}$ duydukları görülmektedir.

Isparta ili kent merkezinde yapılan bir çalışmada tüketicilerin \%61.75'inin ISO standartlarını bildiklerini, HACCP'in ise tüketicilerin \%22.25'i tarafından bilindiği belirtilmiştir (Gül ve ark., 2016). Tokat ilinde yapılan bir çalışmada gıda güvenliği kavramını bilen 102 tüketicinin \%86.30'sının ISO-9000'i duyduğunu, \%10.96'sının ise HACCP'i duyduğu tespit edilmiştir (Gülse Bal ve ark., 2006). Akdeniz bölgesinde yapılan bir araştırmada görüşülen tüketicilerin \%62.9'u ISO standartları hakkında az veya yeterli bilgiye sahip olduklarını, \%32.1'i ise HACCP hakkında az veya yeterli bilgiye sahip olduğunu belirtmiştir (Gül ve ark., 2012a). Ankara ili kent merkezinde yapılan çalışmada ise tüketicilerin \%66'sı ISO standartlarını bildikleri, \%39'u HACCP hakkında bilgi sahibi olduklarını belirtmişlerdir (Taşdan ve ark., 2014). Tüketicilerin ISO 9001 standardı hakkında yüksek oranda bilgi sahibi olduğu fakat HACCP standardı hakkında yeterli bilgi sahibi olmadıkları yapılan diğer çalışmaların bulgularıyla paralellik göstermektedir.

Çizelge 8. Tüketicilerin gıda güvenilirliği ile ilgili kavramlar konusunda bilgisi

Table 8. Consumers knowledge of concepts related to food safety

\begin{tabular}{lccccccccc}
\hline \multirow{2}{*}{ İlgili kavramlar } & \multirow{2}{*}{ Evet/Hayır } & \multicolumn{2}{c}{$\mathrm{I}$} & \multicolumn{2}{c}{ II } & \multicolumn{3}{c}{ III } & \multicolumn{2}{c}{ Toplam } \\
\cline { 3 - 9 } & & $\mathrm{N}$ & $\%$ & $\mathrm{~N}$ & $\%$ & $\mathrm{~N}$ & $\%$ & $\mathrm{~N}$ & $\%$ \\
\hline \multirow{2}{*}{ ISO 9001 } & Evet & 106 & 66.67 & 112 & 70.44 & 44 & 66.67 & 262 & 68.23 \\
& Hayır & 53 & 33.33 & 47 & 29.56 & 22 & 33.33 & 122 & 31.77 \\
\multirow{3}{*}{ ISO 22000 } & Evet & 45 & 28.3 & 66 & 41.51 & 31 & 46.97 & 142 & 36.98 \\
& Hayır & 114 & 71.7 & 93 & 58.49 & 35 & 53.03 & 242 & 63.02 \\
\multirow{3}{*}{ HACCP } & Evet & 34 & 21.38 & 67 & 42.14 & 30 & 45.45 & 131 & 34.11 \\
& Hayır & 125 & 78.62 & 92 & 57.86 & 36 & 54.55 & 253 & 65.89 \\
ISO 14001 & Evet & 15 & 9.43 & 35 & 22.01 & 16 & 24.24 & 66 & 17.19 \\
& Hayır & 144 & 90.57 & 124 & 77.99 & 50 & 75.76 & 318 & 82.81 \\
\hline
\end{tabular}

Araştırma kapsamında bazı değişkenler ile tüketicilerin gıda güvenilirliğini kavramını bilme arasında ilişki olup olmadığı varyans analizi ile ortaya konmuştur. Gıda güvenilirliğini kavramını bilme durumu tüketicilerin bu kavramın tanımıyla ilgili seçeneklere verdiği yanıtla belirlenmiştir. $H_{0}$ : Ilgili değişkenler ile gıda güvenilirliğini bilme arasında ilişki yoktur. $\mathrm{H}_{1}$ : illgili değişkenler ile gıda güvenilirliğini bilme arasında ilişki vardır. Yapılan analiz sonuçlarına göre gıda güvenilirliğini bilme ile tüketicilerin ISO 9001'i bilmesi, ambalaj üzerindeki bilgileri okuması ve tüketicilerin eğitim durumu arasında istatistiki olarak fark olduğu tespit edilmiştir. Gıda güvenilirliğini bilme ile tüketicilerin geliri, yaşı, medeni durumu ve cinsiyeti arasında ise istatistiki olarak bir fark bulunamamıştır (Çizelge 9). 
Çizelge 9. Varyans analizi sonuçları

Table 9. Variance analysis results

\begin{tabular}{lcccc}
\hline \multirow{2}{*}{ Sosyo-ekonomik değişkenler } & \multicolumn{4}{c}{ Hesaplamalar } \\
\cline { 2 - 5 } & $\mathrm{F}_{\text {hesap }}$ & $\mathrm{F}_{\text {cetvel }}$ & P değeri & Kabul/Ret \\
\hline ISO 9001 bilme & 3.966 & 3.841 & 0.046 & $\mathrm{H}_{0}:$ Ret \\
Ambalaj üzerindeki bilgileri okuma & 32.37 & 13.277 & 0.000 & $\mathrm{H}_{0}:$ Ret $* *$ \\
Birey geliri & 0.501 & 5.911 & 0.778 & $\mathrm{H}_{0}$ : Kabul \\
Birey yaşı & 2.236 & 3.841 & 0.135 & $\mathrm{H}_{0}$ : Kabul \\
Birey eğitimi & 20.373 & 11.345 & 0.001 & $\mathrm{H}_{0}:$ Ret \\
Birey medeni durumu & 2.222 & 3.841 & 0.136 & $\mathrm{H}_{0}:$ Kabul \\
Birey cinsiyeti & 0.255 & 3.841 & 0.614 & $\mathrm{H}_{0}:$ Kabul \\
\hline
\end{tabular}

*\%5 önem düzeyi, **\%1 önem düzeyi

Sonuç olarak, artan dünya nüfusu, insanların beslenme alışkanlıklarının değişmesi, günümüzde de yaşanan (korona virüs) küresel boyuttaki salgınlar tüketicileri daha güvenilir gıdalara yöneltmiştir. Bu çalışma ile tüketicilerin gıda ürünlerini satın alırken etkili olan faktörlerin tespit edilmesi ve gıda güvenilirliği hakkındaki bilgi düzeylerinin belirlenmesi amaçlanmıştır.

Tüketicilerin gıda ürünlerini satın alma kararlarına etki eden en önemli faktörler ürünlerin son kullanma tarihleri ve etiket bilgileri olduğu belirlenmiştir. Tüketicilerin gıda güvenilirliğini bilmeleri ile eğitim durumları arasında ilişki bulunmuştur. Ayrıca tüketicilerin büyük çoğunluğunun gıda güvenilirliği konusunda bilgi edindikleri kaynağın radyo ve televizyon programları olduğu saptanmıştır. Bu bağlamda kamuoyunda gıda güvenilirliği konusunda eğitim programları düzenlenebilir ve yapılacak çalışmalarda yayım aracı olarak radyo ve televizyon programları tercih edilebilir. Tüketicilerin gıda ürünlerini satın alırken etiket bilgilerine dikkat ettikleri tespit edilmiş olup güvenilir gıda sistemlerine uygun koşullarda üretilen gıdaların ambalajlarında etiket bilgilerinin daha anlaşıır ve açıklayıcı olması tüketicileri güvenilir gıdayı satın almaya teşvik edecektir.

\section{ÖZET}

Amaç: Bu araştırmada, Konya ili merkez ilçelerinde (Selçuklu, Meram ve Karatay) yaşayan tüketicilerin sosyo-ekonomik özellikleri, gıda satın alırken etkili olan faktörlerin belirlenmesi, gıda güvenilirliği konusunda bilgi düzeylerinin ortaya konulması amaçlanmıştır.

Yöntem ve Bulgular: Araştırmanın ana materyalini Konya ili merkezinde 384 tüketiciden anket yoluyla toplanan veriler oluşturmuştur. Soru cevapları likert ölçeğinde alınmıştır. Çapraz tablolama ile veriler sunulmuş, bazı sosyo-ekonomik değişkenlerle gıda güvenilirliği bilgisi varyans analizi ile test edilmiştir.
Araştırma bulgularına göre tüketicilerin önemli bölümü gıda güvenilirliği kavramını duymuştur. Ancak tüketicilerin yarısından fazlasının gıda güvenilirliği kavramını bildiği tespit edilmiştir. Gıda güvenliği kavramı ile ISO 9001'i bilinmesi, ambalaj üzerindeki bilgileri okunması, bireylerin eğitim durumu değişkenleri arasında istatistiki olarak bir ilişki bulunmaktadır.

Genel Yorum: Tüketicilerin uluslararası gıda güvenilirliği sertifikalarını bilmesi ve eğitim durumunun yükselmesi, gıda güvenilirliği bilgisini artırmaktadır.

Çalışmanın Önemi ve Etkisi: Tüketicilerin gıda güvenilirliği konusunda bilgi düzeyleri ve farkındalığı eğitim seviyelerinin artması ile iyileştirilebilecektir. Kamuoyunun farkındalık konusunda çalışmalarını bu yönde geliştirmesi önemlidir.

Anahtar Kelimeler: Gıda güvenilirliği, tüketici, farkındalık, Konya.

\section{ÇIKAR ÇATIŞMA BEYANI}

Yazar(lar) çalışma konusunda çıkar çatışmasının olmadığını beyan eder.

\section{ARAŞTIRMACILARIN KATKI ORANI BEYANI}

Yazarlar çalışmaya eşit oranda katkı sağlamış olduklarını beyan eder.

\section{KAYNAKLAR}

Akpınar MG, Özkan B, Gül H (2007) Avrupa birliği gıda tüketim trendi. Dünya Gıda 12: 75-79.

Akpınar MG, Gül M (2010) Türkiye'de kentsel alanda hane halklarının su tasarrufuna yönelik tutumları, içme suyunda sağlık riski duyarlılıkları ve tüketim tercihlerinin belirlenmesi: Akdeniz Bölgesi örneği. TÜBiTAK Proje No: 108K606, Ankara, 155s. 
Asseal H (1992) Consumer Behavior and Marketing Action. PSW-Kent Publishing Company, New York University, Boston, USA. pp 747.

Ataseven Y, Arısoy H, Köksal Ö (2012) Türkiye'de tarım politikalarının gıda güvencesi ve güvenliği açısından değerlendirilmesi. 10. Ulusal Tarım Ekonomisi Kongresi, Eylül 5-7, Konya, Türkiye. 174-181s.

Atayata F (2013) Toplu yemek sektöründe sürdürülebilir gıda kalitesi ve gıda güvenliğinin sağlanması. Yüksek Lisans Tezi, İstanbul Üniversitesi, Sağlık Bil. Ens., Besin Hijyeni ve Teknolojisi ABD, $150 \mathrm{~s}$.

Dölekoğlu CÖ, Şahin A, Giray, FH (2015) Kadınlarda fonksiyonel gıda tüketimini etkileyen faktörler: Akdeniz illeri örneği, Tarım Bilim. Derg. 21: 572-584.

Durmaz Dayılar Ö (2018) Gıda güvenliği kavramı bilinç düzeyinin belirlenmesi. Yüksek Lisans Tezi, Selçuk Üniversitesi, Sağlık Bil. Ens., Veterinerlik Besin Hijyeni Ve Teknolojisi ABD, $99 \mathrm{~s}$.

Gül H, Kart FM, Gül M, Akpınar MG (2017) Bakery products consumption and consumers' awareness in urban areas of Isparta city, Turkey. Sci. Pap. Ser. Man. Eco. Eng. in Agr. and Rur. 17: 137-146.

Gül H, Özmen C, Ak Metin S, Gül M (2016) Isparta ilinde tüketicilerin bisküvi ürünleri tüketimi ve tercihleri. 12. Ulusal Tarım Ekonomisi Kongresi, Mayıs 25-27, Isparta, Türkiye. 1903-1912s.

Gül M, Akpınar MG, Dağıstan E (2012a) Meyve suyu tüketimi konusunda toplumsal bilinç düzeyi ve optimum ürün tasarımının analizi: Akdeniz Bölgesi örneği. TÜBiTAK Proje No: 110K085, Ankara, 161s.

Gül M, Akpınar MG, Dağıstan E (2012b) The analysis of households' purchasing preferences for fruit juice in Turkey. JFAE. 10: 119-123.

Gürer B, Akyol E (2018) Tüketicilerin bal tüketiminde gıda güvenilirliği bilincinin incelenmesi: Niğde ili örneği. Turk. Tarım Gıda Bilim Teknol. Derg. 6: 1303-1310.

Gürsoy ỉba S (2013) Uluslararası güvenlik anlayışında gıda güvenliği anlayışında gıda güvenliği sorunsalı: Avrupa Birliği-Türkiye karşılaştırmalı analizi. Doktora Tezi, İstanbul Üniversitesi, Sosyal Bil. Ens., Avrupa Birliği ABD, 242 s.

Halaç E (2002) Gıda kalitesi ve gıda mevzuatı ile ilgili temel kavramlar ışığında Türk ve $A B$ gıda mevzuatının karşılaştırılması. Akdeniz iiBF Dergisi 2: 107-131.
Kadim F, Ar H, Güçubuk B (2014) Gıda güvenilirliği açısından kırsal alandaki kadınlar ve aile çiftçiliğinin önemi. Ulusal Aile Çiftçiliği Sempozyumu, Ekim 30-31, Ankara, Türkiye. 261-267s.

Karlı B, Bilgiç A, Miran B (2008) Consumers' perceptions about genetically modified foods and their stated willingness-to-pay for genetically modified food labeling: evidences from Turkey. Southern Agricultural Economics Association Annual Meeting, February 2-6, Dallas, Texas, United States. pp 15.

Koç B, Ceylan M (2009) Consumer-awareness and information sources on food safety: A case study of Eastern Turkey. NFS 39: 643-654.

Kurtuluş K (1998) Pazarlama Araştırmaları. Avcıol Basım Yayın, Genişletilmiş Altıncı Baskı, İstanbul. 851s.

Madenci AB, Türker S, Bayramoğlu Z, Eyiz V (2019) Tüketicilerin gıda güvenliğine yönelik tutum ve algılarını etkileyen sosyo-ekonomik faktörler: Konya ili örneği. HEAD 1: 48-59.

Onurlubaş E (2015) Tüketicilerin gıda güvenliği konusunda bilinç düzeylerinin ölçülmesi: Tokat ili örneği. Doktora Tezi, Gaziosmanpaşa Üniversitesi, Fen Bil. Ens., Tarım Ekonomisi ABD, $180 \mathrm{~s}$.

Onurlubaş E, Gürler AZ (2016) Gıda güvenliği konusunda tüketicilerin bilinç düzeyini etkileyen faktörler. JAFAG 33: 132-141.

Özdamar K (1999) Paket Programlar ile İstatistiksel Veri Analizi 1. Kaan Kitabevi 2. Baskı, No: 1, ISBN 9756787-00-7, Eskişehir. 535s.

Sağdıç M, Gül M (2016) Dünyada tarım kaynaklı sorunlar. Bölüm 14. In: Günümüz Dünya Sorunları (Ed. Aydın F) Pegem Akademi Yayınları, 485-505s.

Taşdan H, Albayrak M, Gürer B, Özer OO, Albayrak K, Güldal HT (2014) Geleneksel gıdalarda tüketicilerin gıda güvenliği algısı: Ankara ili örneği. 2. Uluslararası Davraz Kongresi, Mayıs 29-31, Isparta, Türkiye. 15s.

Yılmaz Y, Semerci A, Tapkı N, Dağıstan E, Konuşkan DB (2015) Consumers' knowledge, attitudes and behavior assessment about food safety: the case study of Hatay province of Turkey. TURJAF 3: 672679. 